Title

\title{
Association between asthma and suicidality in 9-11-year-old children
}

\section{Authors}

Kevin W. Hoffman ${ }^{1}$, Elina Visoki ${ }^{2,3}$, Stirling T. Argabright ${ }^{2,3}$, Grace E. Didomenico ${ }^{2,3}$, Barbara H. Chaiyachati $^{1,2,4}$, Tyler M. Moore ${ }^{1,2}$, Ran Barzilay ${ }^{1,2,3}$

${ }^{1}$ Department of Psychiatry, Perelman School of Medicine, University of Pennsylvania, Philadelphia, US

${ }^{2}$ Lifespan Brain Institute of Children's Hospital of Philadelphia and Penn Medicine, Philadelphia, US

${ }^{3}$ Department of Child and Adolescent Psychiatry and Behavioral Science, Children's Hospital of Philadelphia, Philadelphia, US

${ }^{4}$ Department of General Pediatrics, Children's Hospital of Philadelphia, Philadelphia, US

\section{Corresponding Author:}

Corresponding author: Ran Barzilay MD PhD, 10th floor, Gates Building, Hospital of the University of Pennsylvania, 34th and Spruce Street, Philadelphia, PA 19104

Email: ran.barzilay@pennmedicine.upenn.edu

Tel: +1 (484) 6957937

\section{Short running title}

Asthma and suicidality in children

\section{Keywords}

Suicidality, asthma, immune dysregulation, inflammation, children 


\begin{abstract}
Background: Suicidal thoughts and behavior (STB) in children are a growing health concern, and more data is needed regarding their biological underpinnings. Immune processes such as inflammation have been associated with STB, primarily in adults. Asthma is a common chronic inflammatory disorder in children and has been associated with STB in adolescent and adult populations, but data in children is lacking. We wished to study associations of asthma with childhood STB given asthma's potential as a clinically relevant model for childhood chronic immune dysregulation.
\end{abstract}

Methods: Using data from the Adolescent Brain Cognitive Development (ABCD) Study ( $N=11,878$, $52 \%$ males, mean age 9.9 years at baseline assessment and 10.9 years at 1 -year follow up), we assessed associations between asthma and STB at both baseline and 1-year follow up.

Results: We found that asthma at baseline assessment $(n=2,214,18.6 \%)$ is associated with STB, controlling for multiple confounders including demographics, socioeconomic factors and environmental confounders such as air pollution (odds ratio $(\mathrm{OR})=1.2,95 \% \mathrm{Cl} 1.01-1.42, \mathrm{P}=0.039$ ). Indicators of recently active asthma were not significantly associated with suicidality at baseline assessment (currently taking asthma medication: $\mathrm{OR}=1.22,95 \% \mathrm{Cl} 0.93-1.60, \mathrm{P}=0.146$ ), or at 1 year follow up (past year asthma-related clinical visit: $\mathrm{OR}=1.13,95 \% \mathrm{Cl} 0.87-1.47, \mathrm{P}=0.357$ ). Proxymeasures of asthma severity (number of asthma medications or clinical visits) did not reveal a significant dose response relationship with STB.

Conclusions: Findings suggest an association between history of asthma and STB in children, which may not be related to asthma disease state. Further research is needed to investigate mechanisms underlying this relationship. 


\section{Introduction}

Compromised physical health and inflammatory dysregulation are associated with suicidal behaviors (1-3). Children with asthma commonly possess both of these traits. Asthma has been independently associated with suicide risk in adolescent and adult populations (4), but more data is needed in children and early adolescents. Considering that asthma is the most common chronic disease in children, with steadily increasing rates, understanding suicide risk in this population is critical (5). Compounding this urgency is a steadily increasing rate of suicidal thoughts and behaviors (STB) in children aged $10-14$ years (6-9).

While asthma itself is associated with STB risk, it is frequently controlled with medications that should also be assessed for STB risk. Recently, the asthma medication Montelukast was required by the FDA to carry a boxed warning for serious mental health side effects including suicidal thoughts or actions following observational study of 15 years of use (10). Other studies have additionally linked asthma medications with suicide risk in adults (11). Similar associations have been reported between immune modulating drugs and STB in adults $(11,12)$.

The purpose of this study was to evaluate the association of asthma and asthma medication use with STB in 9-11-year-old children. We hypothesized that asthma, as an example of an immune dysregulation illness, would be associated with childhood STB. We used data obtained from the Adolescent Brain Cognitive Development (ABCD) Study (13), a large, diverse youth sample $(\mathrm{N}>11,000)$ with extensive phenotyping for sociodemographic factors, psychopathology, medical conditions and treatments, and multiple environmental exposures (14). 


\section{Methods and Materials}

\section{Study design}

We employed a cross-sectional design examining associations between history of asthma or current use of asthma medications and STB at baseline ABCD Study assessment, and the association between past-year asthma/asthma attack and STB in 1-year follow-up assessment.

\section{Sample}

The sample is composed of all ABCD Study participants who completed the baseline assessment $(\mathrm{N}=11,878)$ or the 1 -year follow-up assessment $(\mathrm{N}=11,235)$. The $A B C D$ Study sample includes a cohort of children aged 9-10 years at baseline, recruited through school systems (15). Participants were enrolled at 21 sites, with catchment area encompassing over $20 \%$ of the entire US population in this age group. We included data from the ABCD Study data release 3.0 (https://abcdstudy.org/). All participants gave assent. Parents/caregivers signed informed consent. The ABCD Study protocol was approved by the University of California, San Diego Institutional Review Board (IRB), and was exempted from a full review by University of Pennsylvania IRB.

\section{Exposures}

A history of asthma was considered for all participants that endorsed at least one of the following items at baseline assessment: parent report of asthma diagnosis at baseline assessment (referred throughout the manuscript as parent report, variable medhx_2a from the $A B C D$ Summary Scores Medical History); parent report of asthma attack for which the participant was seen by a healthcare provider (referred throughout the manuscript as asthma attack, variable medhx_6I from the ABCD Summary Scores Medical History); and parent report of child taking 
asthma medications in the past 2 weeks (referred throughout as asthma medications, also assessed at baseline, data from the ABCD Parent Medications Survey Inventory). We created a composite measure of these measures referred throughout the manuscript as asthma composite, or simply, asthma.

Recently active asthma was considered for all participants that endorsed at least one of the following items at the 1-year follow-up assessment: having been to the doctor since the baseline assessment for asthma (variable medhx_2a_l) or for asthma attack (variable medhx_6l_I).

Asthma medications taken in the past 2 weeks (binary variable) as reported at baseline ABCD Study assessment included: beta-agonists, inhaled corticosteroids, leukotriene modifiers, and others (see Supplementary Table 1 for a full list of asthma medications).

Asthma severity was estimated by two variables available at the baseline assessment: a) The number of parent-reported clinical visits due to asthma attacks (medhx_ss_6l_times_p, continuous variable); and b) The number of asthma medications that the participant was taking (continuous variable).

\section{Outcome measures}

The ABCD Study assessed suicidal ideation and attempt (past or current) as part of the validated and computerized Kiddie-Structured Assessment for Affective Disorders and Schizophrenia for DSM-5 (KSADS-5) (16). Items relating to self-injurious behavior without suicidal intent were not included in the current analysis. As the proportion of suicide attempts was low, and to mitigate risk of type I error caused by multiple testing, we combined suicidal ideation and attempt, consistent with previous analyses $(17,18)$. Thus, STB was defined as a single binary 
measure termed "suicidality," considered for children who endorsed past/present suicidal ideation (SI) and/or suicide attempt (SA) at ABCD Study baseline or 1-year follow-up assessment. Prevalence of SI and SA is detailed in Supplementary Table 2. As prior studies (including in the ABCD Study) showed poor youth-caregiver agreement on STB (18-20), we focused on childreport in the current analysis.

\section{Covariates}

Covariates were obtained from ABCD Study baseline data and included demographics: age, sex, race (Black, White, Other), and Hispanic ethnicity (used in Model 1 described below); household-level socioeconomic status (SES) variables: household income, average parent education, and maternal age (added in Model 2 described below); and neighborhood-level factors: area deprivation index, population density, $\mathrm{NO}_{2}$ and PM 2.5 (annual average at $10 \times 10 \mathrm{~km}^{2}$ ), and proximity to major roads (added in Model 3 described below).

\section{Statistical Analysis}

We used the SPSS 26.0 statistical package and R for our data analyses. Mean (standard deviation [SD]) and frequency (\%) were reported for descriptive purposes. Univariate comparisons were made using t-tests or chi-square tests, as appropriate. We employed listwise deletion for participants with missing data, the rate of which was lower than $2.3 \%$ for all variables except neighborhood-level variables (5.9\%) and household income (8.6\%).

The analytic plan and hypotheses were preregistered on Open Science Framework (https://osf.io/nxeys/) in July 2021 and analyses were conducted in August-September 2021. Data preprocessing and analysis detailed at https://github.com/barzilab1/ABCD asthma inflammation k. 


\section{Main Analyses}

We tested a set of binary logistic regression models with asthma exposures as independent variables (IV) and suicidality as the dependent variable (DV). We first tested models using the baseline data with asthma composite and each of its comprising items (parent report, asthma attack and asthma medications) as IVs, and suicidality as DV. Then, we tested a crosssectional model using the 1-year follow-up data with currently active asthma as IV and suicidality as DV.

In all the above-described models, we added covariates in a stepwise manner, beginning with demographics (Model 1), then adding household-level SES (Model 2), and then adding neighborhood-level exposures (Model 3).

\section{Sensitivity Analyses}

We ran two sensitivity analyses to address the specificity of our findings from the main analyses: to address specificity of the exposure (asthma), we ran similar models as above using the measure "ever seen a doctor for broken bones" (measure medhx_6a in ABCD Study) as the IV; to address the possibility that severity of asthma affects the associations identified in the main analyses, we tested models using proxies of asthma severity ("number of asthma attacks" or "number of asthma medications") as the IV. 
medRxiv preprint doi: https://doi.org/10.1101/2021.10.23.21265416; this version posted October 26, 2021. The copyright holder for this preprint

(which was not certified by peer review) is the author/funder, who has granted medRxiv a license to display the preprint in perpetuity.

It is made available under a CC-BY-NC-ND 4.0 International license.

\section{Results}

Prevalence of Asthma and STB in ABCD

Among 11,878 children at baseline $A B C D$ Study assessment (mean age $=9.9$ years [SD $=0.6]$, 6,196 boys [52.2\%]), 2,214 (18.6\%) endorsed at least one asthma exposure and met our definition as having a history of asthma (asthma composite). Of which, 2,039 (17.2\%) were described by their caregivers as having asthma, $809(6.8 \%)$ had been seen by a medical provider for an asthma attack, and 698 (5.9\%) were taking asthma medications. Overall, 1,040 (8.8\%) reported suicidality. Demographic and clinical characteristics of the baseline sample are detailed in Table 1. 
medRxiv preprint doi: https://doi.org/10.1101/2021.10.23.21265416; this version posted October 26, 2021. The copyright holder for this preprint (which was not certified by peer review) is the author/funder, who has granted medRxiv a license to display the preprint in perpetuity.

It is made available under a CC-BY-NC-ND 4.0 International license .

Table 1: Sample socio-demographics, asthma, and STB prevalence in the ABCD study

\begin{tabular}{|l|c|}
\hline Total sample (baseline) $^{\text {a }}$ & $\mathbf{N = 1 1 , 8 7 8}$ \\
\hline & Mean (SD) \\
\hline Age at baseline assessment, years & $9.92(0.62)$ \\
\hline Sex, male & $\mathbf{n}(\%)$ \\
\hline White & $6,196(52.2 \%)$ \\
\hline Black & $8,805(74.1 \%)$ \\
\hline Asian & $2,518(21.2 \%)$ \\
\hline Hispanic & $752(6.3 \%)$ \\
\hline Asthma variables & $2,411(20.3 \%)$ \\
\hline Parent report of asthma & \\
\hline Asthma attack & $2,039(17.2 \%)$ \\
\hline Asthma medications & $809(6.8 \%)$ \\
\hline Asthma composite ${ }^{\text {b }}$ & $698(5.9 \%)$ \\
\hline Recently active asthma ${ }^{\mathbf{c}}$ & $2,214(18.6 \%)$ \\
\hline Asthma medication variables & $891(7.5 \%)$ \\
\hline Non-steroids (bronchodilators, leukotriene modifiers) & \\
\hline Steroids & $697(5.9 \%)$ \\
\hline Suicidal thoughts and behavior (STB) measures & $46(0.4 \%)$ \\
\hline Ever suicidal ideation (SI) & \\
\hline Ever suicide attempt (SA) & $1,025(8.6 \%)$ \\
\hline Suicidality (ever SI or SA) & $156(1.3 \%)$ \\
\hline
\end{tabular}

${ }^{a}$ For all variables, missing data rate was less than $2.3 \%$ (273 participants out of the 11,878 participants at baseline $A B C D$ assessment).

b A history of asthma was considered for all participants that endorsed at least one of the following items at baseline assessment: parent report of asthma diagnosis at baseline assessment; parent report of asthma attack for which the participant was seen by a healthcare provider; and parent report of child taking asthma medications in the past 2 weeks. ${ }^{\mathrm{C}}$ Recently active asthma was considered for all participants that endorsed at least one of the following items at the 1-year follow-up assessment: having been to the doctor since the baseline assessment for asthma or for asthma attack. 
medRxiv preprint doi: https://doi.org/10.1101/2021.10.23.21265416; this version posted October 26, 2021. The copyright holder for this preprint (which was not certified by peer review) is the author/funder, who has granted medRxiv a license to display the preprint in perpetuity.

It is made available under a CC-BY-NC-ND 4.0 International license .

\section{Association of asthma with suicidality in baseline ABCD Study assessment}

Univariate comparison revealed that children with a history of asthma (asthma composite) endorsed suicidality at higher rates than children without asthma (Table 2), with $10.3 \%$ rate endorsement of suicidality among participants with asthma compared to $8.5 \%$ among the nonasthma participants (Pearson chi-square $(\mathrm{df}=1)=7.119 ; \mathrm{P}=0.008)$. In contrast, there was no difference in rates of suicidality between participants who had ever broken bones $(n=1,706$, of which 9.4\% endorsed suicidality) and those who had not ( $n=10,168$, of those $8.7 \%$ endorsed suicidality, $\mathrm{P}=0.342$ ).

Table 2: Univariate comparison of STB between participants with and without asthma

\begin{tabular}{|c|c|c|c|c|c|c|c|c|c|c|}
\hline & \multicolumn{8}{|c|}{$\begin{array}{c}\text { Baseline data } \\
\text { (ages 9-10) }\end{array}$} & \multirow{2}{*}{\multicolumn{2}{|c|}{$\begin{array}{c}\begin{array}{c}\text { 1-year data } \\
\text { (ages 10-11) }\end{array} \\
\begin{array}{c}\text { Recently active } \\
\text { asthma }\end{array}\end{array}$}} \\
\hline & \multicolumn{2}{|c|}{$\begin{array}{c}\text { Asthma } \\
\text { composite }\end{array}$} & \multicolumn{2}{|c|}{$\begin{array}{l}\text { Parent report } \\
\text { asthma }\end{array}$} & \multicolumn{2}{|c|}{ Asthma attack } & \multicolumn{2}{|c|}{$\begin{array}{c}\text { Asthma } \\
\text { medications }\end{array}$} & & \\
\hline & No & Yes & No & Yes & No & Yes & No & Yes & No & Yes \\
\hline Total, $\mathbf{n}$ & 9,575 & 2,214 & 9,762 & 2,039 & 10,992 & 809 & 11,091 & 698 & 9,809 & 891 \\
\hline $\begin{array}{l}\text { Suicidality, } \\
\text { n (\%) }\end{array}$ & $\begin{array}{c}811 \\
(8.5 \%)\end{array}$ & $\begin{array}{c}227 \\
(10.3 \%)\end{array}$ & $\begin{array}{c}827 \\
(8.5 \%)\end{array}$ & $\begin{array}{c}213 \\
(10.4 \%)\end{array}$ & $\begin{array}{c}950 \\
(8.6 \%)\end{array}$ & $\begin{array}{c}90 \\
(11.1 \%)\end{array}$ & $\begin{array}{c}960 \\
(8.7 \%)\end{array}$ & $\begin{array}{c}78 \\
(11.2 \%)\end{array}$ & $\begin{array}{c}790 \\
(8.1 \%)\end{array}$ & $\begin{array}{c}85 \\
(9.5 \%)\end{array}$ \\
\hline P-value & & 0.008 & & 0.004 & & 0.016 & & 0.023 & & 0.121 \\
\hline
\end{tabular}

Univariate comparison of STB between participants with and without asthma. Reported significance based on comparison of suicidality of children with or without each condition. Parent report of child ever breaking a bone were also compared regarding suicidality. Of those without history of broken bones $(10,102), 880$ (8.7\%) endorsed a history of suicidality. Of those with a history of broken bones (1,699), 160 (9.4\%) endorsed a history of suicidality. The prevalence of suicidality in both populations was not significantly different $(P=0.342)$. Abbreviations: STB= suicidal thoughts and behaviors.

To address the specificity of the above association we conducted multivariable analysis to account for potential confounding effects (Table 3 ). The association between asthma and suicidality was not statistically significant when co-varying for demographic factors (Model 1; 
medRxiv preprint doi: https://doi.org/10.1101/2021.10.23.21265416; this version posted October 26, 2021. The copyright holder for this preprint (which was not certified by peer review) is the author/funder, who has granted medRxiv a license to display the preprint in perpetuity.

It is made available under a CC-BY-NC-ND 4.0 International license .

odds ratio $[\mathrm{OR}]=1.17,95 \%$ confidence interval $[\mathrm{Cl}]$ 0.99-1.37, $\mathrm{P}=0.06)$, but when we co-varied for household SES (measured by income, average parent education, and maternal age), the association was significant (Model 2; $\mathrm{OR}=1.2,95 \% \mathrm{Cl} 1.01-1.42, \mathrm{P}=0.035$ ). The asthma-suicidality association remained significant when including neighborhood environment confounders including area deprivation index, population density, air pollution $\left(\mathrm{NO}_{2}, \mathrm{PM} 2.5\right)$, and proximity to major roads (Model 3; OR=1.2, 95\% Cl 1.01-1.42, $\mathrm{P}=0.039$ ). In contrast to asthma, a history of having broken a bone did not show an association with suicidality in any of the multivariable models (all $\mathrm{P}^{\prime} \mathrm{s}>0.279$ ).

Table 3: Association between asthma and suicidality in the ABCD Study

\begin{tabular}{|c|c|c|c|c|c|c|c|c|c|}
\hline \multirow[b]{2}{*}{ Exposure } & \multicolumn{3}{|c|}{ Model $1^{a}$} & \multicolumn{3}{|c|}{ Model $2^{b}$} & \multicolumn{3}{|c|}{ Model $3^{c}$} \\
\hline & OR & $95 \% \mathrm{Cl}$ & P-value & OR & $95 \% \mathrm{Cl}$ & P-value & OR & $95 \% \mathrm{Cl}$ & P-value \\
\hline $\begin{array}{l}\text { History of asthma } \\
\text { (asthma composite) }^{d}\end{array}$ & 1.17 & $0.99-1.37$ & 0.06 & 1.2 & $1.01-1.42$ & 0.035 & 1.2 & $1.01-1.42$ & 0.039 \\
\hline $\begin{array}{l}\text { Recently active } \\
\text { asthma }\end{array}$ & 1.14 & $0.90-1.45$ & 0.277 & 1.12 & $0.87-1.45$ & 0.384 & 1.13 & $0.87-1.47$ & 0.357 \\
\hline
\end{tabular}

Binary logistic regression models with asthma measures as independent variables and suicidality as the dependent variable.

aModel 1 co-varies for demographics: age, sex, race (Black, White, Other) and Hispanic ethnicity.

${ }^{b}$ Model 2 co-varies for demographics and household-level SES: income, average parent education, and maternal age.

'Model 3 co-varies for demographics, household SES, and neighborhood-level factors: area deprivation index, population density, NO2, PM 2.5, and proximity to major roads.

${ }^{\mathrm{d} A}$ history of asthma was considered for all participants that endorsed at least one of the following items at baseline assessment: parent report of asthma diagnosis at baseline assessment; parent report of asthma attack for which the participant was seen by a healthcare provider; and parent report of child taking asthma medications in the past 2 weeks.

eRecently active asthma was considered for all participants that endorsed at least one of the following items at the 1-year follow-up assessment: having been to the doctor since the baseline assessment for asthma or for asthma attack.

Abbreviations: $\mathrm{OR}=$ odds ratio; $\mathrm{Cl}=$ confidence interval. 
medRxiv preprint doi: https://doi.org/10.1101/2021.10.23.21265416; this version posted October 26, 2021. The copyright holder for this preprint (which was not certified by peer review) is the author/funder, who has granted medRxiv a license to display the preprint in perpetuity.

It is made available under a CC-BY-NC-ND 4.0 International license .

When using different definitions of asthma exposures (that comprise the asthma composite variable), multivariable models showed statistically significant associations with suicidality for the exposures of parent report of asthma and having seen a healthcare provider for asthma attacks, whereas none of the multivariable models showed a significant association between taking asthma medications and suicidality (Supplementary Table 3).

\section{Association of having recently active asthma with suicidality in the 1-year follow-up ABCD Study assessment}

Among participants of the 1-year follow-up ABCD Study assessment (mean age 10.9), no significant difference was observed comparing suicidality rates among participants having recently active asthma (estimated by going to see a doctor for asthma/asthma attack in the time between baseline and 1-year follow up ABCD Study assessment) compared to their counterparts (9.5\% Vs $8.1 \%, P=0.121$, Table 2 ). Multivariable analyses revealed no association of recently active asthma with suicidality (Table 3; when co-varying for demographics, household SES and neighborhood factors: $\mathrm{OR}=1.13,95 \% \mathrm{Cl} 0.0 .87-1.47, \mathrm{P}=0.357)$.

\section{Association of asthma severity proxies with suicidality}

To explore a possible dose relationship between asthma severity and suicidality, we evaluated two metrics of asthma severity proxies that are available in the ABCD Study baseline data: reported number of asthma attacks and total number of asthma medications. While both measures showed a direction of association that might suggest a dose response, there was not a statistically significant association in any of the tested models (in models that co-varied for 
medRxiv preprint doi: https://doi.org/10.1101/2021.10.23.21265416; this version posted October 26, 2021. The copyright holder for this preprint (which was not certified by peer review) is the author/funder, who has granted medRxiv a license to display the preprint in perpetuity. It is made available under a CC-BY-NC-ND 4.0 International license.

demographics, household SES and neighborhood factors: OR for each additional clinical visit due to asthma attack=1.04, 95\% $\mathrm{Cl}$ 0.99-1.1, $\mathrm{P}=0.113$; OR for each additional asthma medication=1.11, 95\% Cl 0.95-1.29, P=0.203, see Supplementary Table 4 for full models' statistics). 
medRxiv preprint doi: https://doi.org/10.1101/2021.10.23.21265416; this version posted October 26, 2021. The copyright holder for this preprint (which was not certified by peer review) is the author/funder, who has granted medRxiv a license to display the preprint in perpetuity.

It is made available under a CC-BY-NC-ND 4.0 International license .

\section{Discussion}

We describe an association between history of asthma and suicidality in a large, diverse sample of preadolescent US children (age 9-10). The association was significant when accounting for multiple SES household variables and neighborhood confounders. Furthermore, sensitivity analyses showing a lack of association with suicidality of a non-inflammatory medical condition (bone fractures), further supports the specificity of findings. These results add to existing literature on the associations between asthma and suicidality in adolescents (21-25) and adults (26-35), and support the biological evidence for an association between immune dysregulation and suicidality (36-38), presenting early in the lifespan. Notably, while suicidality itself is an important target for investigation in terms of its association with immune dysregulation (39), it may also be a key non-specific indicator of significant psychological distress in young children. Indeed, early life suicidality is strongly tied to stress exposure (40-42), which in turn is associated with immune dysregulation $(43,44)$. Our findings therefore provide a clinical indication for the link between inflammation (i.e., asthma) and suicidality, and support the notion that immune mechanisms may be involved in the development of suicidality.

While asthma is common, it is not evenly distributed across the population, with different prevalence between genders, racial groups, SES, and populations from urban vs rural settings $(45,46)$. Similarly, gender, race, and SES, all associated with various levels of discrimination, are all associated with youth suicidality (47-51). A major strength of the ABCD Study is that its large sample size and deep phenotyping allows sufficient power to account for all the above potential confounders and support the specificity of our findings showing a positive association of asthma and childhood suicidality. Notably, while this association remained significant for all three multivariable models for asthma identified by parent report (demographic in Model 1; household 
medRxiv preprint doi: https://doi.org/10.1101/2021.10.23.21265416; this version posted October 26, 2021. The copyright holder for this preprint (which was not certified by peer review) is the author/funder, who has granted medRxiv a license to display the preprint in perpetuity.

It is made available under a CC-BY-NC-ND 4.0 International license .

SES in Model 2; neighborhood environment in Model 3), the exposure of taking asthma medications did not show significant association with suicidality in any of the models, with substantial decrease in statistical significance once SES was included in the model $(P=0.069$ for Model $1, \mathrm{P}=0.123,0.126$ for Models 2 and 3 respectively). One potential explanation for this finding is that inadequate access to asthma medication in children from lower-resourced SES backgrounds may be confounding the association between taking asthma medication and suicidality.

In addition to the asthma-suicidality association in baseline data at ages 9-10, we used the 1-year follow up $A B C D$ Study data to attempt to assess whether recently active asthma (seeing a doctor for asthma or asthma attack in the past year) is associated with suicidality, and found no evidence to support such association. Furthermore, the fact that in the baseline data, there was no association between currently taking asthma medication and suicidality may also indicate a lack of association between the recency of active asthma and suicidality. Together these findings might suggest that it is a history of asthma (i.e., "trait"), rather than active asthma (i.e., "state"), that drives the association with suicidality. It is possible that underlying asthma factors, such as chronic immune dysregulation, and not factors relating to asthma attacks themselves (e.g., psychological distress from asthma symptoms) explain the association observed between asthma and suicidality. In this case, the state of having asthma would be expected to be associated with suicidality, but proximity to an asthma attack (and consequently the increased likelihood of taking asthma medications) would not necessarily be associated with suicidality, especially as the power to detect these effects diminishes when narrowing on a population with 
medRxiv preprint doi: https://doi.org/10.1101/2021.10.23.21265416; this version posted October 26, 2021. The copyright holder for this preprint (which was not certified by peer review) is the author/funder, who has granted medRxiv a license to display the preprint in perpetuity. It is made available under a CC-BY-NC-ND 4.0 International license .

recently active disease ( $n=891$ with recently active asthma compared to $n=2,214$ with a history of asthma in the current study).

As a final aim, we wished to investigate possible dose relationships between asthma and suicidality. Establishing a dosage effect helps build an argument for a causal relationship between two correlated factors and can potentially shed light on mechanisms through which asthma may influence suicidality. The two severity metrics we chose (lifetime number of asthma attacks and total number of asthma medications) were chosen because they provided both medicationindependent and -dependent measures of severity, which provides a means of distinguishing between suicide risk driven by asthma vs suicide risk driven by asthma medications. While neither metric showed statistical significance, both correlations showed a positive direction, suggesting that our study population may have been underpowered to address these questions. It is also possible that we were looking at the wrong dose relationship. If the correlation between asthma and suicidality is primarily driven by inflammatory dysregulation or common genetic linkages, it may be the case that the number of asthma attacks or asthma medications is irrelevant to suicide risk and instead inflammatory or genetic factors may alternatively establish causality.

This study suggests a clinical association between asthma and suicidality in children and should propel future research aiming to identify mechanisms that drive this association. A few mechanisms have been previously proposed to explain the connection between asthma and suicidality (4). First, asthma symptoms may cause psychological distress consequently leading to suicidality. Second, asthma's immune dysregulation may drive increased depression $(52,53)$, which in turn drives increased suicidality. Third, there may be common genetic linkages between asthma and mood. While originally proposed to explain a connection between asthma and 
depression, this framework is useful for suicidality as well, with the added consideration that asthma medications themselves may drive suicidality, as evidenced by growing concern surrounding Montelukast (54).

Given these proposed mechanisms and the results of our study, several avenues of investigation present themselves. Future studies that include medical records of children with asthma may allow for greater power to assess associations between asthma medications and suicidality, and in-depth psychological assessment of the subset endorsing suicidality may further allow investigation between specific asthma symptoms and suicidality. Additionally, if, as we hypothesize, immune dysregulation is important in the link between asthma and suicide, similar associations would be expected in children subject to other immune dysregulatory and proinflammatory processes. Finally, our results lay the groundwork for future genetic studies investigating linkages between asthma and suicidality in youth.

\section{Limitations}

Our findings should be viewed in light of several limitations. First, the ABCD Study was not intended specifically to address this study's questions, hence the phenotyping for asthma and its severity was established without a clinician's rating and/or specific asthma scales, and we relied instead on parent report of asthma diagnosis, report of asthma attacks, and asthma medications. Another limitation is the cross-sectional nature of this study. More studies are needed to investigate longitudinal relationships between asthma and suicidality in the ABCD Study and other cohorts. Additionally, the current study does not include biological measures of immune dysregulation, which should be explored in future works as ABCD Study releases biological 
medRxiv preprint doi: https://doi.org/10.1101/2021.10.23.21265416; this version posted October 26, 2021. The copyright holder for this preprint

(which was not certified by peer review) is the author/funder, who has granted medRxiv a license to display the preprint in perpetuity. It is made available under a CC-BY-NC-ND 4.0 International license.

specimens that can allow immune phenotyping. Lastly, while the ABCD Study is large, including

21 sites across the US, our findings need to be generalized and replicated in other youth datasets.

\section{Conclusions}

This study describes an association between history and asthma and suicidality in a large community sample of preadolescent children. The large number of children studied, the withinsample diversity, and the broad nature of data collected allowed controlling for multiple confounders, providing a basis to investigate mechanisms underpinning this asthma-suicidality association. 
medRxiv preprint doi: https://doi.org/10.1101/2021.10.23.21265416; this version posted October 26, 2021. The copyright holder for this preprint (which was not certified by peer review) is the author/funder, who has granted medRxiv a license to display the preprint in perpetuity.

It is made available under a CC-BY-NC-ND 4.0 International license .

Conflict of Interest Disclosures: Dr Barzilay serves on the scientific board and reports stock ownership in 'Taliaz Health', with no conflict of interest relevant to this work. All other authors have no conflicts of interest do declare.

Funding/Support: This study was supported by the National Institute of Mental Health grants 5R25MH119043 (KWH), RO1MH117014 (TMM), K23MH120437 (RB), R21MH123916 (RB), and the Lifespan Brain Institute of Children's Hospital of Philadelphia and Penn Medicine, University of Pennsylvania.

Acknowledgement: Data used in the preparation of this article were obtained from the Adolescent Brain Cognitive DevelopmentSM (ABCD) Study (https://abcdstudy.org), held in the NIMH Data Archive (NDA). This is a multisite, longitudinal study designed to recruit more than 10,000 children age $9-10$ and follow them over 10 years into early adulthood. The ABCD Study ${ }^{\circledR}$ is supported by the National Institutes of Health and additional federal partners under award numbers U01DA041048, U01DA050989, U01DA051016, U01DA041022, U01DA051018, U01DA051037, U01DA050987, U01DA041174, U01DA041106, U01DA041117, U01DA041028, U01DA041134, U01DA050988, U01DA051039, U01DA041156, U01DA041025, U01DA041120, U01DA051038, U01DA041148, U01DA041093, U01DA041089, U24DA041123, U24DA041147. A full list of supporters is available at https://abcdstudy.org/federal-partners.html. A listing of participating sites and a complete listing of the study investigators can be found at https://abcdstudy.org/consortium_members/. ABCD consortium investigators designed and implemented the study and/or provided data but did not necessarily participate in analysis or writing of this report. This manuscript reflects the views of the authors and may not reflect the opinions or views of the NIH or ABCD consortium investigators. 
medRxiv preprint doi: https://doi.org/10.1101/2021.10.23.21265416; this version posted October 26, 2021. The copyright holder for this preprint (which was not certified by peer review) is the author/funder, who has granted medRxiv a license to display the preprint in perpetuity. It is made available under a CC-BY-NC-ND 4.0 International license.

Role of the Funder/Sponsor: The funding organization had no role in the design and conduct of the study; collection, management, analysis, and interpretation of the data; preparation, review, or approval of the manuscript; and decision to submit the manuscript for publication. 
medRxiv preprint doi: https://doi.org/10.1101/2021.10.23.21265416; this version posted October 26, 2021. The copyright holder for this preprint (which was not certified by peer review) is the author/funder, who has granted medRxiv a license to display the preprint in perpetuity. It is made available under a CC-BY-NC-ND 4.0 International license .

References:

1. Li Z, Page A, Martin G, Taylor R (2011): Attributable risk of psychiatric and socio-economic factors for suicide from individual-level, population-based studies: A systematic review. Social Science and Medicine 72: 608-616.

2. Brundin L, Bryleva EY, Thirtamara Rajamani K (2017): Role of inflammation in suicide: From mechanisms to treatment. Neuropsychopharmacology 42: 271-283.

3. de Leo D, Scocco P, Marietta P, Schmidtke A, Bille-Brahe U, Kerkhof AJFM, et al. (1999): Physical illness and parasuicide: Evidence from the European parasuicide study interview schedule (EPSIS/WHO-EURO). International Journal of Psychiatry in Medicine 29: 149-163.

4. Barker E, Kãlves K, de Leo D (2015): The relationship between asthma and suicidal behaviours: A systematic literature review. European Respiratory Journal 46: 96-106.

5. Ferrante G, la Grutta S (2018): The burden of pediatric asthma. Frontiers in Pediatrics 6: 186.

6. Naghavi M (2019): Global, regional, and national burden of suicide mortality 1990 to 2016: Systematic analysis for the Global Burden of Disease Study 2016. BMJ (Clinical research ed) 364: 194.

7. Janiri D, Doucet GE, Pompili M, Sani G, Luna B, Brent DA, Frangou S (2020): Risk and protective factors for childhood suicidality: A US population-based study. The Lancet Psychiatry 7: 317-326.

8. Burstein B, Agostino H, Greenfield B (2019): Suicidal attempts and ideation among children and adolescents in US emergency departments, 2007-2015. JAMA pediatrics 173: 598-600.

9. Carbone JT, Holzer KJ, Vaughn MG (2019): Child and adolescent suicidal ideation and suicide attempts: Evidence from the healthcare cost and utilization project. Journal of Pediatrics 206: 225-231.

10. Neuropsychiatric events following montelukast use: A propensity score matched analysis. (2019): Retrieved February 20, 2021, from https://www.sentinelinitiative.org/assessments/drugs/neuropsychiatric-events-followingmontelukast-use-propensity-score-matched

11. Gorton HC, Webb RT, Kapur N, Ashcroft DM (2016): Non-psychotropic medication and risk of suicide or attempted suicide: A systematic review. BMJ Open 6: e009074.

12. Bostwick JM, Warrington TP (2006): Psychiatric adverse effects of corticosteroids. Mayo Clin Proc 81: 1361-7.

13. Volkow ND, Koob GF, Croyle RT, Bianchi DW, Gordon JA, Koroshetz WJ, et al. (2018): The conception of the ABCD study: From substance use to a broad NIH collaboration. Developmental Cognitive Neuroscience 32: 4-7.

14. Barch DM, Albaugh MD, Avenevoli S, Chang L, Clark DB, Glantz MD, et al. (2018): Demographic, physical and mental health assessments in the adolescent brain and cognitive development study: Rationale and description. Developmental Cognitive Neuroscience 32: 55-66.

15. Garavan H, Bartsch H, Conway K, Decastro A, Goldstein RZ, Heeringa S, et al. (2018): Recruiting the $A B C D$ sample: Design considerations and procedures. Developmental Cognitive Neuroscience 32: 16-22.

16. Kaufman J, Birmaher B, Brent D, Rao U, Flynn C, Moreci P, et al. (1997): Schedule for affective disorders and schizophrenia for school-age children-present and lifetime version 
medRxiv preprint doi: https://doi.org/10.1101/2021.10.23.21265416; this version posted October 26, 2021. The copyright holder for this preprint (which was not certified by peer review) is the author/funder, who has granted medRxiv a license to display the preprint in perpetuity. It is made available under a CC-BY-NC-ND 4.0 International license .

(K-SADS-PL): Initial reliability and validity data. Journal of the American Academy of Child and Adolescent Psychiatry 36: 980-988.

17. Shoval G, Visoki E, Moore TM, Didomenico GE, Argabright ST, Huffnagle NJ, et al. (2021): Evaluation of attention-deficit/hyperactivity disorder medications, externalizing symptoms, and suicidality in children. JAMA Network Open 4: e2111342.

18. DeVille DC, Whalen D, Breslin FJ, Morris AS, Khalsa SS, Paulus MP, Barch DM (2020): Prevalence and family-related factors associated with suicidal ideation, suicide attempts, and self-injury in children aged 9 to 10 years. JAMA network open 3: e1920956.

19. Zalsman G, Shoval G, Mansbach-Kleinfeld I, Farbstein I, Kanaaneh R, Lubin G, Apter A (2016): Maternal versus adolescent reports of suicidal behaviors: a nationwide survey in Israel. European Child and Adolescent Psychiatry 25: 1349-1359.

20. Klaus NM, Mobilio A, King CA (2009): Parent-adolescent agreement concerning adolescents' suicidal thoughts and behaviors. Journal of clinical child and adolescent psychology: the official journal for the Society of Clinical Child and Adolescent Psychology, American Psychological Association, Division 53 38: 245.

21. Bandiera FC, Ramirez R, Arheart KL, Canino G, Goodwin RD (2013): Asthma and suicidal ideation and behavior among Puerto Rican older children and adolescents. Journal of Nervous and Mental Disease 201: 587-591.

22. Bae J, Park EY, Park SW (2011): Modifying effect of suicidal ideation on the relationship between asthma and cigarette use behaviors among Korean adolescents. Journal of Preventive Medicine and Public Health 44: 118-124.

23. Bender BG (2007): Depression symptoms and substance abuse in adolescents with asthma. Annals of Allergy, Asthma and Immunology 99: 319-324.

24. Goodwin RD, Marušič A (2004): Asthma and suicidal ideation among youth in the community. Crisis 25: 99-102.

25. Kuo CJ, Chen VCH, Lee WC, Chen WJ, Ferri CP, Stewart R, et al. (2010): Asthma and suicide mortality in young people: A 12-year follow-up study. American Journal of Psychiatry 167: 1092-1099.

26. Bolton JM, Walld R, Chateau D, Finlayson G, Sareen J (2015): Risk of suicide and suicide attempts associated with physical disorders: a population-based, balancing score-matched analysis. Psychological Medicine 45: 495-504.

27. Nomura Y, Brooks-Gunn J, Davey C, Hasm J, Fifer WP (2007): The role of perinatal problems in risk of co-morbid psychiatric and medical disorders in adulthood. Psychological Medicine 37: 1323-1334.

28. Goodwin RD, Eaton WW (2005): Asthma, suicidal ideation, and suicide attempts: Findings from the Baltimore Epidemiologic Catchment Area follow-up. American Journal of Public Health 95: 717-722.

29. Goodwin RD, Demmer RT, Galea S, Lemeshow AR, Ortega AN, Beautrais A (2012): Asthma and suicide behaviors: Results from the Third National Health and Nutrition Examination Survey (NHANES III). Journal of Psychiatric Research 46: 1002-1007.

30. Druss B, Pincus H (2000): Suicidal ideation and suicide attempts in general medical illnesses. Archives of Internal Medicine 160: 1522-1526. 
medRxiv preprint doi: https://doi.org/10.1101/2021.10.23.21265416; this version posted October 26, 2021. The copyright holder for this preprint (which was not certified by peer review) is the author/funder, who has granted medRxiv a license to display the preprint in perpetuity. It is made available under a CC-BY-NC-ND 4.0 International license .

31. Yen YC, Yang MJ, Yang MS, Lung FW, Shih CH, Hahn CY, Lo HY (2005): Suicidal ideation and associated factors among community-dwelling elders in Taiwan. Psychiatry and Clinical Neurosciences 59: 365-371.

32. Goodwin RD, Olfson M, Shea S, Lantigua RA, Carrasquilo O, Gameroff MJ, Weissman MM (2003): Asthma and mental disorders in primary care. General Hospital Psychiatry 25: 479483.

33. Bolton JM, Walld R, Chateau D, Finlayson G, Sareen J (2015): Risk of suicide and suicide attempts associated with physical disorders: a population-based, balancing score-matched analysis. Psychological Medicine 45: 495-504.

34. Singhal A, Ross J, Seminog O, Hawton K, Goldacre MJ (2014): Risk of self-harm and suicide in people with specific psychiatric and physical disorders: comparisons between disorders using English national record linkage: Journal of the Royal Society of Medicine 107: 194204.

35. Crump C, Sundquist K, Sundquist J, Winkleby MA (2014): Sociodemographic, psychiatric and somatic risk factors for suicide: A Swedish national cohort study. Psychological Medicine 44: 279-289.

36. Brundin L, Bryleva EY, Thirtamara Rajamani K (2017): Role of inflammation in suicide: From mechanisms to treatment. Neuropsychopharmacology 42: 271-283.

37. Jha MK, Cai L, Minhajuddin A, Fatt CC, Furman JL, Gadad BS, et al. (2020): Dysfunctional adaptive immune response in adolescents and young adults with suicide behavior. Psychoneuroendocrinology 111: 104487.

38. Ganança L, Oquendo MA, Tyrka AR, Cisneros-Trujillo S, Mann JJ, Sublette ME (2016): The role of cytokines in the pathophysiology of suicidal behavior. Psychoneuroendocrinology 63: 296-310.

39. Neupane SP (2021): Psychoneuroimmunology: The new frontier in suicide research. Brain, Behavior, \& Immunity - Health 17: 100344.

40. Carballo JJ, Llorente C, Kehrmann L, Flamarique I, Zuddas A, Purper-Ouakil D, et al. (2019): Psychosocial risk factors for suicidality in children and adolescents. European Child \& Adolescent Psychiatry 29: 759-776.

41. Stewart JG, Shields GS, Esposito EC, Cosby EA, Allen NB, Slavich GM, Auerbach RP (2019): Life stress and suicide in adolescents. Journal of abnormal child psychology 47: 1707.

42. Barzilay R, Moore TM, Calkins ME, Maliackel L, Jones JD, Boyd RC, et al. (2021): Deconstructing the role of the exposome in youth suicidal ideation: Trauma, neighborhood environment, developmental and gender effects. Neurobiology of Stress 14: 100314.

43. Glaser R, Kiecolt-Glaser JK (2005): Stress-induced immune dysfunction: implications for health. Nature Reviews Immunology 2005 5:3 5: 243-251.

44. Gouin J-P, Hantsoo L, Kiecolt-Glaser JK (2008): Immune dysregulation and chronic stress among older adults: A review. Neuroimmunomodulation 15: 251.

45. Lawson JA, Rennie DC, Cockcroft DW, Dyck R, Afanasieva A, Oluwole O, Afsana J (2017): Childhood asthma, asthma severity indicators, and related conditions along an urban-rural gradient: a cross-sectional study. BMC Pulmonary Medicine 17: 1-9.

46. Current Asthma Demographics | American Lung Association (n.d.): Retrieved September 14, 2021, from https://www.lung.org/research/trends-in-lung-disease/asthma-trendsbrief/current-demographics 
47. Hoffmann JA, Farrell CA, Monuteaux MC, Fleegler EW, Lee LK (2020): Association of pediatric suicide with county-level poverty in the United States, 2007-2016. JAMA Pediatrics 174: 287-294.

48. Ruch DA, Sheftall AH, Schlagbaum P, Rausch J, Campo J v., Bridge JA (2019): Trends in suicide among youth aged 10 to 19 years in the United States, 1975 to 2016. JAMA Network Open 2: e193886-e193886.

49. Plemmons G, Hall M, Doupnik S, Gay J, Brown C, Browning W, et al. (2018): Hospitalization for suicide ideation or attempt: 2008-2015. Pediatrics 141: 20172426.

50. Bridge JA, Horowitz LM, Fontanella CA, Sheftall AH, Greenhouse J, Kelleher KJ, Campo J v. (2018): Age-related racial disparity in suicide rates among US youths from 2001 through 2015. JAMA Pediatrics 172: 697-699.

51. Argabright ST, Visoki E, Moore TM, Ryan DT, DiDomenico GE, Njoroge WFM, et al. (2021): Association between discrimination stress and suicidality in preadolescent children. Journal of the American Academy of Child \& Adolescent Psychiatry. Aug 20;508908567(21)01355-1. Online ahead of print

52. Irwin MR, Miller AH (2007): Depressive disorders and immunity: 20 years of progress and discovery. Brain, Behavior, and Immunity 21: 374-383.

53. di Marco F, Santus P, Centanni S (2011): Anxiety and depression in asthma. Current Opinion in Pulmonary Medicine 17: 39-44.

54. FDA requires Boxed Warning about serious mental health side effects for asthma and allergy drug montelukast (Singulair); advises restricting use for allergic rhinitis | FDA (n.d.): Retrieved September 24, 2021, from https://www.fda.gov/drugs/drug-safety-andavailability/fda-requires-boxed-warning-about-serious-mental-health-side-effects-asthmaand-allergy-drug 
